Abstracta Iranica Abstracta Iranica

Revue bibliographique pour le domaine irano-aryen

Volume 28 | 2007

Comptes rendus des publications de 2005

\title{
« Être jeune militant nationaliste azéri en Iran ». CEMOTI, n 38, juillet-décembre 2004, pp. 205-235.
}

\section{Azadeh Kian-Thiébaut}

\section{OpenEdition}

1 Journals

\section{Édition électronique}

URL : http://journals.openedition.org/abstractairanica/19391

DOI : 10.4000/abstractairanica. 19391

ISSN : 1961-960X

Éditeur :

CNRS (UMR 7528 Mondes iraniens et indiens), Éditions de l'IFRI

\section{Édition imprimée}

Date de publication : 15 mai 2007

ISSN : 0240-8910

Référence électronique

Azadeh Kian-Thiébaut, « «Être jeune militant nationaliste azéri en Iran ». CEMOTI, n 38, juilletdécembre 2004, pp. 205-235. », Abstracta Iranica [En ligne], Volume 28| 2007, document 438, mis en ligne le 18 septembre 2007, consulté le 25 septembre 2020. URL : http://journals.openedition.org/ abstractairanica/19391 ; DOI : https://doi.org/10.4000/abstractairanica.19391

Ce document a été généré automatiquement le 25 septembre 2020.

Tous droits réservés 


\title{
« Être jeune militant nationaliste azéri en Iran ». CEMOTI, n 38 , juillet-décembre 2004, pp. 205-235.
}

\author{
Azadeh Kian-Thiébaut
}

1 L'A. analyse l'engagement nationaliste des jeunes azéris en Iran et leur éthos militant. Il décrit une jeunesse post-islamiste qui a largement profité des progrès socio-éducatifs de la République islamique mais ne se reconnaît pas dans les normes et les valeurs promues par le pouvoir. Grâce à une analyse des espaces de recrutement, l'A. explique comment ces jeunes se sont familiarisés avec le discours nationaliste azéri. L'analyse se tourne ensuite vers les logiques de l'engagement militant, que ce soit en terme de déterminants ou de rétributions. L'attention portée à l'expérience vécue permet de mettre en évidence l'importance des dimensions affectives et identitaires, et le besoin de se sentir valorisés ressenti par ces jeunes. Enfin la dimension cognitive de l'engagement est abordée en questionnant la notion d'habitus : elle trace une ligne de fracture entre des jeunes militants préparés à l'expression d'énoncés de la réflexivité $\mathrm{du}$ Soi et d'autres qui s'engagent dans une contestation de leur univers de sens où apparait un manque profond de cohérences des représentations du monde. Ces différences dans l'engagement, liées à la socialisation primaire, dessinent les contours d'une jeunesse iranienne polysémique qui a en commun des inquiétudes et des problèmes, mais les exprime de manière différenciée.

\section{INDEX}

Thèmes : 13.1. Iran 


\section{AUTEURS}

\section{AZADEH KIAN-THIÉBAUT}

Université Paris VIII / Mondes iranien et indien 